\title{
Family dynamics during the grieving process: a systematic literature review
}

\author{
Mayra Delalibera ${ }^{1}$ \\ Joana Presa ${ }^{2}$ \\ Alexandra Coelho ${ }^{2}$ \\ António Barbosa ${ }^{2}$ \\ Maria Helena Pereira Franco ${ }^{3}$
}

${ }^{1}$ Instituto Superior de Psicologia Aplicada. R. Jardim do Tabaco 34 , Centro. 1149-041 Lisboa Estremadura Portugal. mayrarmani@yahoo.com.br ${ }^{2}$ Núcleo Académico de Estudos e Intervenção sobre o Luto, Centro de Bioética da Faculdade de Medicina Universidade de Lisboa.

${ }^{3}$ Laboratório de Estudos e Intervenção sobre o Luto, Pontifícia Universidade Católica de São Paulo.

\begin{abstract}
The loss of a loved one can affect family dynamics by changing the family system and creating the need for family members to reorganize. Good family functioning, which is characterized by open communication, expression of feelings and thoughts and cohesion among family members, facilitates adaptive adjustment to the loss. This study conducted a systematic review of the literature on family dynamics during the grieving process. A search was conducted in the EBSCO, Web of Knowledge and Bireme databases for scientific articles published from January 1980 to June 2013. Of the 389 articles found, only 15 met all the inclusion criteria. The selected studies provided evidence that dysfunctional families exhibit more psychopathological symptoms, more psychosocial morbidity, poorer social functioning, greater difficulty accessing community resources, lower functional capacity at work, and a more complicated grieving process. Family conflicts were also emphasized as contributing to the development of a complicated grieving process, while cohesion, expression of affection and good communication in families are believed to mitigate grief symptoms.

Key words Family dynamics, Family functioning, Grief, Systematic review
\end{abstract}




\section{Introduction}

Caring for a family member with a serious and progressive disease is often stressful. The experience generates anxiety and can cause changes in family dynamics because often the whole family is directly or indirectly involved in the care process. Caring for a sick person, especially at home, involves a number of practical tasks associated with ensuring the patient's comfort and physical and emotional well being ${ }^{1}$.

According to Kramer et al. ${ }^{2}$, few studies have examined how family conflict and experiences of care at the end of life may influence the grieving process of family caregivers. Grief, a natural and expected reaction to the loss of a loved one, is both an individual and a family experience. A loss can affect the family's functioning and dynamics because the family, an integrated system of relationships, is changed forever and its members are required to reorganize ${ }^{3}$.

There may, therefore, be family system characteristics that affect an individual's grieving process; each individual differs in the expression of his or her own grief $f^{4}$. The grieving experience can be enhanced or impaired by the openness of communication and level of cohesion among family members ${ }^{5}$. Therefore, good family functioning during the caregiving phase and especially during the grieving process is important for the psychological well-being of family members.

When a family functions well, mutual support among its members contributes to adaptive adjustment to loss. Open communication and free expression of feelings and thoughts, family cohesion and the constructive resolution of differences of opinion are crucial for a functional family facing stressful life situations because when family functioning is more limited, its members have greater difficulty adapting ${ }^{6}$.

Research has been conducted ${ }^{2,7-12}$ to better understand family functioning and the changes that occur after the loss of a loved one. In 1981, Moss and Moss ${ }^{13}$ developed the Family Relationships Index (FRI), a subscale of the Family Environment Scale (FES). This instrument evaluates three dimensions of family dynamics: cohesion among family members, level of conflict and freedom to express thoughts and feelings. According to Kissane et al. ${ }^{9,10}$, five types of family functioning can be identified based on these dimensions: functional types, including supportive and conflict resolving families; intermediate families; and dysfunctional families, including sullen and hostile families.
Supportive families have high cohesion and report no conflicts. Conflict resolving families have high cohesion and a moderate level of conflict ${ }^{9}$. These families are functional, tolerate differences of opinion among their members, address conflicts constructively through effective communication and have low levels of psychosocial morbidity ${ }^{14}$. Intermediate families manifest moderate cohesion among their members and a low level of conflict and are more prone to psychosocial morbidity, and their functioning tends to deteriorate when exposed to the pressure of loss and grief ${ }^{9,14}$.

Sullen families have moderate cohesion, a moderate level of conflict, and a lack of desire for help. Hostile families have a low level of cohesion, seldom express feelings and thoughts, manifest a high level of conflict among family members and tend to reject help from others. These dysfunctional families have high rates of psychosocial morbidity, including depression ${ }^{9,14}$. Studies have reported that high psychosocial morbidity levels are positively correlated with poorer family functioning ${ }^{11,14}$.

An individual's family type can influence the way its members experience the grieving process and vice versa. The family environment can contribute decisively to psychosocial morbidity, including depressive symptoms, anxiety and alcohol abuse. These problems may exist before the loss and continue into the grieving period ${ }^{6,9}$.

Studies examining the correlation between family dynamics and grief primarily report that families classified as dysfunctional and intermediate are at greatest risk and exhibit significantly higher levels of depressive symptoms and psychological morbidity. These families also have the worst overall social adjustment and adjust poorly to work and social and leisure activities. They also have little or no social support ${ }^{6,10,11}$.

Family conflicts also contribute to the non-resolution of grief ${ }^{10}$. Families with higher levels of conflict have worse family functioning ${ }^{15,16}$; a history of conflict in the family is a strong predictor of family conflict at the end of life ${ }^{17}$.

Few studies have examined the association between family dynamics and the grieving process. The aim of this systematic literature review is therefore to group and summarize the studies that have been performed and verify the instruments most commonly used to evaluate family dynamics and the grieving process.

This study conducted a systematic review of the literature on the effect of family dynamics on adult family members' grieving process. 


\section{Method}

A broad search for scientific articles published only in scientific journals between January 1980 and June 2013 was performed in the EBSCO (PsycInfo, PsycArticles, Psychology and Behavioral Sciences Collection, Academic Search Complete), Web of Knowledge (Web of Science and MEDLINE) and Bireme (Lilacs, IBECS, MedLine, Cochrane Library, SciELO) databases.

The search terms used included grief or bereave $^{\star}$ or mourning. These keywords were associated (and) with the following terms: family functioning, family relations, family dynamic, dysfunctional families, family conflict. All possible combinations were investigated. In the $\mathrm{Bi}-$ reme database, a search was performed using the same terms in Portuguese (e.g., funcionamento familiar and luto, relações familiares and luto, etc.).

The following inclusion criteria were used: empirical articles published in scientific journals in English, Portuguese or Spanish that evaluated family dynamics during the grieving period. The following types of articles were excluded: theoretical articles, opinions and commentaries, articles in which the sample did not consist of adult family members and studies investigating perinatal loss. Master's theses and doctoral dissertations were not included in the research.

The articles were evaluated and selected according to the inclusion and exclusion criteria. The initial selection was performed by reading the title and abstract of each article. The exclusion of duplicates was performed by the principal author (MD) (Figure 1). Two independent investigators (MD and JP) read the selected articles in their entirety and completed a second selection round, which included an evaluation of the studies' quality. Doubts or disagreements were resolved by a third investigator (AC).

To evaluate the quality of the studies, an evaluation tool developed by the authors was used. Its criteria were based on an evaluation criteria checklist for use in observational studies (the STROBE statement) published by von Elm et al. ${ }^{18}$ The instrument consists of 10 questions worth between 0 and 2 points; the maximum score is 20 points. The total score is obtained by summing the scores of the items. Higher scores indicate higher-quality studies.

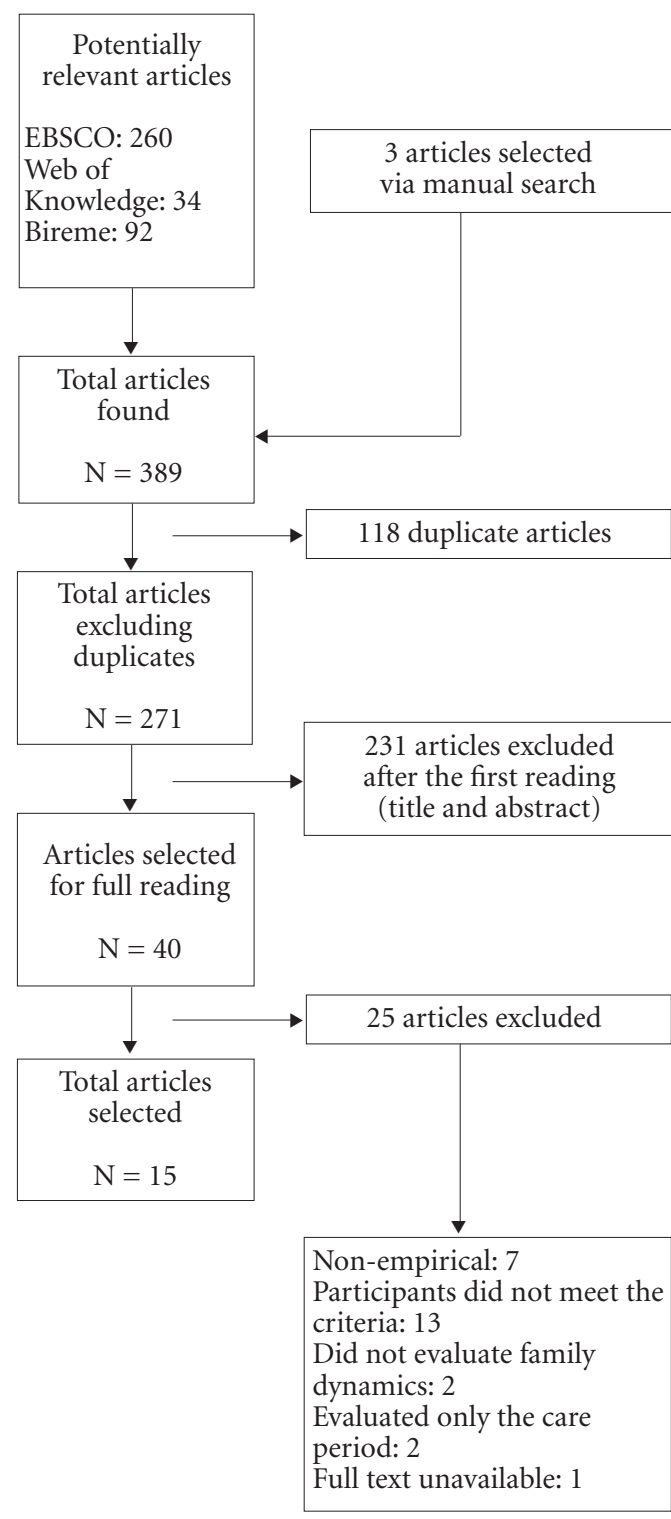

Figure 1. Process for selecting the articles included in the review.

\section{Results}

Of the 389 articles found, 118 were duplicates and 231 were excluded in the first selection round because they were not related to the research question, did not evaluate the variables in question, did not meet the inclusion criteria or were not empirical articles. Forty articles were read in their entirety, but only fifteen articles met all the inclusion criteria.

Twenty-five studies were excluded after being read completely. Seven of these articles were not 
empirical studies but were only literature updates; in thirteen of the articles, the participants did not meet the inclusion criteria (relatives of cancer survivors, children or adolescents, health professionals); two of the articles did not evaluate the family dynamics variable; in two of the articles, the authors only performed evaluations in the care phase and not during the grieving process; and it was not possible to access the full text of one of the articles (Figure 1).

Chart 1 presents the articles selected for analysis and their study quality evaluation scores. The selected articles were published between 1992 and 2013. Nine of the studies were performed in the United States and six in Australia. Regarding the publishing sources, one article was located in each of the following journals: Cancer Practice, Palliative Medicine, Death Studies, Psycho-Oncology and the International Journal of Palliative Nursing. Two of the articles were published in the Journal of Family Nursing, three in The American Journal of Psychiatry and five in Omega: Journal of Death and Dying.

Regarding the study design, seven of the studies were cross-sectional and eight longitudinal. The longitudinal ones evaluated participants at up to three steps that ranged from the beginning of the grieving process until 24 months after the family member's death. In seven of the studies, the deceased family members were cancer patients, two of whom were children. One study investigated patients in palliative care. In five studies, the deceased family members were children and adolescents who had died a sudden and/or violent death. In two studies, the cause of death was not specified. In one study, only spouses of the deceased participated; in two, spouses and children. Five investigations included parents (couples), one only mothers and another parents and children. In four studies, participants were required to have a partner and at least one child over 12 years old to complete the instruments and be categorized as a family member. Another study characterized family members as couples with at least one child. Sample sizes ranged between 37 and 363 participating family members (Chart 1).

All the studies evaluated family dynamics, and five studies used more than one instrument for this purpose. Eight of the studies evaluated grief using specific instruments; eight evaluated psychopathological symptoms using the BSI (Brief Symptom Inventory ); four used instruments specifically designed to evaluate depression (BDI - Beck Depression Inventory); two studies evaluated anxiety and depression using the DASS-21 (Depression Anxiety Stress Scales); and two articles evaluated social functioning using the SAS (Social Adjustment Scale).

The instrument most commonly used to evaluate family dynamics was the FACES III (Family Adaptability and Cohesion Evaluation Scale), followed by the FAD (Family Assessment Device), the FES (Family Environment Scale) and the FRI (Family Relationship Index). Studies that used the FES employed either its full form or the family relationships subscale. The FAM (Family Assessment Measure) was also used, as were Bloom's family scales for evaluating family functioning. One study employed the FC-EOL (Family Conflict at the End of Life), which evaluates family conflict (Table 1). To evaluate grief, most studies used the BPQ (Bereavement Phenomenology Questionnaire) or the ICG (Inventory of Complicated Grief). The TRIG (Texas Revised Inventory of Grief), the CGI (Core Grieving Inventory) and the GEI (Grief Experience Inventory) were also used (Table 2).

To better explain the results, the selected articles were divided into groups according to the cause of death of the deceased family member. The earliest relevant study was performed by Jordan in $1992^{21}$. This study found that husbands with higher rates of sudden death in their families tended to be more dissatisfied with family functioning and that husbands with higher rates of traumatic death in their families tended to have wives and children who were more dissatisfied with family functioning. Wives who reported higher levels of stress and had a history of more losses in their families reported more psychological symptoms, worse satisfaction with their families and had more similarities to the group of couples and families who reported lower levels of cohesion, greater divergence in perception of family functioning between husbands and wives, and a family organization that deviated more from general population norms.

However, the most recent study, which also does not specify the cause of death of the participants' family members, found that families that were more cohesive, freely expressed affection and had better communication after a loss had fewer grief symptoms six months after the loss, i.e., they experienced a less intense grieving process $^{12}$.

Kissane et al. ${ }^{9,10}$ studied participants whose family members died from cancer or received palliative care. They screened and classified the families according to the typology described 
Chart 1. Articles selected for evaluation.

\begin{tabular}{|c|c|c|c|c|c|c|c|}
\hline $\begin{array}{l}\text { Authors } \\
\text { and year }\end{array}$ & Country & Objective & Design & Population & Instruments & Results & $\begin{array}{c}\text { Quality } \\
\text { Eval. }\end{array}$ \\
\hline $\begin{array}{l}\text { Brintzenhofeszoc, } \\
\text { Smith, \& Zabora } \\
(1999)^{7}\end{array}$ & USA & $\begin{array}{l}\text { Identify those } \\
\text { at risk of } \\
\text { complicated } \\
\text { grief by } \\
\text { studying the } \\
\text { relationship } \\
\text { between } \\
\text { family } \\
\text { functioning, } \\
\text { psychological } \\
\text { distress and } \\
\text { the family's } \\
\text { grief reaction } \\
\text { after death }\end{array}$ & $\begin{array}{l}\text { Cross- } \\
\text { sectional }\end{array}$ & $\begin{array}{l}37 \text { spouses } \\
\text { of deceased } \\
\text { cancer } \\
\text { patients }\end{array}$ & $\begin{array}{l}\text {-FACES III }{ }^{\mathrm{a}} \text { (family } \\
\text { dynamics) } \\
\text {-TRIG (grief) } \\
\text {-BSI }^{\mathrm{b}} \\
\text { (psychopathological } \\
\text { symptoms) }\end{array}$ & $\begin{array}{l}\text { - } 48 \% \text { of families had } \\
\text { an intermediate or } \\
\text { adapted level of family } \\
\text { functioning, } \\
\text { - anxiety, depression } \\
\text { and distress correlated } \\
\text { positively with grief } \\
\text { reactions, } \\
\text { - the higher the level } \\
\text { of depression and } \\
\text { anxiety, the greater } \\
\text { the likelihood of } \\
\text { complicated grief, } \\
\text { - the more } \\
\text { dysfunctional the } \\
\text { family, the more } \\
\text { complicated the grief } \\
\text { reaction, } \\
\text { - the more distressed } \\
\text { and depressed the } \\
\text { surviving spouse, the } \\
\text { greater the likelihood } \\
\text { of developing } \\
\text { complicated grief. }\end{array}$ & 18 \\
\hline $\begin{array}{l}\text { Drew, } \\
\text { Goodenough, } \\
\text { Maurice, } \\
\text { Foreman, Willis } \\
(2005)^{20}\end{array}$ & Australia & $\begin{array}{l}\text { Investigate the } \\
\text { psychological } \\
\text { distress, } \\
\text { family } \\
\text { functioning } \\
\text { and } \\
\text { complicated } \\
\text { grief of } \\
\text { parents whose } \\
\text { children died } \\
\text { of cancer } \\
\text { and the } \\
\text { relationship } \\
\text { of these } \\
\text { factors to } \\
\text { whether the } \\
\text { child received } \\
\text { a transplant } \\
\text { and the child's } \\
\text { place of death }\end{array}$ & $\begin{array}{l}\text { Cross- } \\
\text { sectional }\end{array}$ & $\begin{array}{l}56 \text { grieving } \\
\text { parents } \\
\text { divided into } \\
2 \text { groups: } \\
\text { those whose } \\
\text { children had } \\
\text { received a } \\
\text { transplant } \\
\text { and those } \\
\text { whose } \\
\text { children did } \\
\text { not receive a } \\
\text { transplant }\end{array}$ & $\begin{array}{l}\text { - DASS- } 21^{\mathrm{d}} \\
\text { (depression, } \\
\text { anxiety, } \\
\text { and stress) } \\
\text { - CBI (grief) } \\
\text { - ICG (grief) } \\
\text { - FAD } \text { (family }^{\mathrm{f}} \\
\text { dynamics) }\end{array}$ & $\begin{array}{l}\text { - there were no } \\
\text { significant differences } \\
\text { between the groups } \\
\text { with regard to family } \\
\text { functioning, } \\
\text { - the parents of the } \\
\text { children who received } \\
\text { a transplant reported } \\
\text { relatively higher levels } \\
\text { of depression, anxiety } \\
\text { and stress, } \\
\text { - parents whose } \\
\text { child received a } \\
\text { transplant and also } \\
\text { died in the hospital } \\
\text { were more likely to } \\
\text { meet the criteria for } \\
\text { complicated grief } \\
\text { than parents whose } \\
\text { deceased child had not } \\
\text { received a transplant. }\end{array}$ & 18 \\
\hline
\end{tabular}

above. Their two articles, published in the same journal issue, described one longitudinal study and revealed that a family's typology as identified at the first evaluation point in the study predict- 


\begin{tabular}{|c|c|c|c|c|c|c|c|}
\hline \multicolumn{8}{|c|}{ Chart 1. continuation } \\
\hline $\begin{array}{l}\text { Authors } \\
\text { and year }\end{array}$ & Country & Objective & Design & Population & Instruments & Results & $\begin{array}{l}\text { Quality } \\
\text { Eval. }\end{array}$ \\
\hline $\begin{array}{l}\text { Gooodenough, } \\
\text { Drew, Higgins } \\
\text { \& Trethewie } \\
(2004)^{21}\end{array}$ & Australia & $\begin{array}{l}\text { Evaluate long- } \\
\text { term grief and } \\
\text { psychological } \\
\text { outcomes as } \\
\text { a function of } \\
\text { the parents' } \\
\text { gender and the } \\
\text { child's place of } \\
\text { death (home or } \\
\text { hospital) }\end{array}$ & $\begin{array}{l}\text { Cross- } \\
\text { sectional }\end{array}$ & $\begin{array}{l}50 \text { parents }(25 \\
\text { mothers, } 25 \\
\text { fathers) whose } \\
\text { child had died of } \\
\text { cancer at least } 1 \\
\text { year ago }\end{array}$ & $\begin{array}{l}\text { - FAD (family } \\
\text { dyn.) } \\
\text { - DASS- } 21 \\
\text { (depression, } \\
\text { anxiety, and } \\
\text { stress) } \\
\text { - ICG (grief) }\end{array}$ & $\begin{array}{l}\text { - no significant } \\
\text { results in terms of } \\
\text { family functioning, } \\
\text { - fathers and } \\
\text { mothers whose } \\
\text { child died in the } \\
\text { hospital had higher } \\
\text { depression results, } \\
\text { - fathers whose } \\
\text { child died in the } \\
\text { hospital reported } \\
\text { significantly } \\
\text { higher levels of } \\
\text { depression, anxiety } \\
\text { and stress, } \\
\text { - mothers showed } \\
\text { no differences with } \\
\text { regard to place } \\
\text { of death but had } \\
\text { more complicated } \\
\text { grief symptoms } \\
\text { than fathers }\end{array}$ & 18 \\
\hline
\end{tabular}

it continues

ed its classification at the second and third steps (six and thirteen months after the death of the family member, respectively). Families classified as functional (supportive and conflict resolving) experienced more successful grief resolution, made more adaptive adjustments and used more coping strategies. Sullen families experienced a more intense grieving process and greater psychosocial morbidity (increased risk of depression) but made more use of religious, social and community resources. Hostile and sullen families experienced poorer social adjustment, experienced poorer social and overall functioning and were also less functional at work. Hostile families reported little or no social support.

Brintzenhofeszoc et al. ${ }^{7}$ reported that forty-eight percent of the families they studied had an intermediate or adapted family functioning level. They observed that the more dysfunctional the family was, the more complicated the reaction could be to the loss of a loved one. Furthermore, the more anxiety and depression symptoms presented by the surviving spouse, the greater the likelihood was of him/her developing complicated grief.

In a study published in 2003, Kissane and colleagues $^{11}$ evaluated the psychosocial morbidity of grieving families and found that dysfunctional families had poor social, overall, domestic and leisure functioning and greater psychosocial morbidity. They also reported worse relationships with their children. Hostile families were more likely to have depressed, anxious and obsessive members than other families, higher levels of anxiety and poorer social adjustment. Sullen families had higher levels of anger and higher scores on the psychosis and paranoid ideation subscales.

In a study published in 2006, Kissane et al. ${ }^{14}$ performed a randomized controlled trial of family grief therapy intervention. The experimental group underwent therapeutic intervention, and both the experimental group and the control group were evaluated at three steps before therapy began, immediately after the loss of the loved one and six and thirteen months after the death of the family member. The authors concluded 


\begin{tabular}{|c|c|c|c|c|c|c|c|}
\hline \multicolumn{8}{|c|}{ Chart 1. continuation } \\
\hline $\begin{array}{l}\text { Authors } \\
\text { and year }\end{array}$ & Country & Objective & Design & Population & Instruments & Results & $\begin{array}{c}\text { Quality } \\
\text { Eval. }\end{array}$ \\
\hline $\begin{array}{l}\text { Jordan } \\
(1992)^{19}\end{array}$ & USA & $\begin{array}{l}\text { Examine the } \\
\text { relationship } \\
\text { between } \\
\text { accumulated } \\
\text { stress, four- } \\
\text { generation loss } \\
\text { history and } \\
\text { current family } \\
\text { functioning of } \\
\text { family members }\end{array}$ & $\begin{array}{l}\text { Cross- } \\
\text { sectional }\end{array}$ & $\begin{array}{l}24 \text { bereaved } \\
\text { families ( } 3 \\
\text { people in } \\
\text { each family) }\end{array}$ & $\begin{array}{l}\text { - FILE (stressors in } \\
\text { family history) } \\
\text { - FHQ } \\
\text { (information on } \\
\text { deaths in the } \\
\text { family) } \\
\text { - FIF } \\
\text { (socioeconomic }^{\mathrm{i}} \\
\text { data) } \\
\text { - BSI } \\
\text { (psychopathological } \\
\text { symptoms) }\end{array}$ & $\begin{array}{l}\text { - husbands with higher rates } \\
\text { of sudden death in their } \\
\text { family histories tended to be } \\
\text { more dissatisfied with family } \\
\text { functioning, } \\
\text { - husbands with higher rates } \\
\text { of traumatic death tended to } \\
\text { have wives and children who } \\
\text { were more dissatisfied with } \\
\text { the family, } \\
\text {-wives who reported higher } \\
\text { levels of stress and greater } \\
\text { history of losses tended } \\
\text { to belong to couples and } \\
\text { families that reported lower } \\
\text { levels of cohesion, greater } \\
\text { divergence in perceptions } \\
\text { about family functioning } \\
\text { between husbands and wives, } \\
\text { and a family organization } \\
\text { that deviated more from } \\
\text { general population norms, } \\
\text { - higher stress levels and } \\
\text { history of loss in wives } \\
\text { was a poor predictor of } \\
\text { satisfaction with the family } \\
\text { and was associated with more } \\
\text { psychological symptoms, } \\
\text { - the best family functioning } \\
\text { predictor was the wife's } \\
\text { history of stressors and } \\
\text { previous losses, not current } \\
\text { stressors. }\end{array}$ & 18 \\
\hline
\end{tabular}

that family-oriented grief therapy had the potential to reduce the complications of grief and pathological grief. They further found that, over 13 months, psychological distress, as evaluated by the BSI, was reduced significantly more than among the control group, as was depression, except among hostile families in the experimental group. Subjects in the experimental group with high distress and depression scores at the first evaluation showed significant improvement in these indices after the intervention. The benefit was most pronounced for intermediate and sullen families, who achieved better results after the therapeutic intervention. The conflict levels of the intermediate families in the experimental group were reduced significantly more than those of the intermediate families in the control group six months after the loss. However, hostile families should receive special attention because their conflict levels increased over the course of thirteen months.

The Kramer et al. study ${ }^{2}$, also conducted with cancer patients, revealed that families who experience more family conflict at the end of the sick person's life show more complicated grief symptoms. 
Chart 1. continuation

\begin{tabular}{|c|c|c|c|c|c|c|c|}
\hline $\begin{array}{l}\text { Authors } \\
\text { and year }\end{array}$ & Country & Objective & Design & Population & Instruments & Results & $\begin{array}{c}\text { Quality } \\
\text { Eval. }\end{array}$ \\
\hline $\begin{array}{l}\text { Kissane, } \\
\text { Bloch, } \\
\text { Dowe, } \\
\text { Snyder, } \\
\text { Onghena, } \\
\text { McKenzie, } \\
\text { \& Wallace } \\
(1996)^{9}\end{array}$ & Australia & $\begin{array}{l}\text { Identify family } \\
\text { functioning } \\
\text { patterns in } \\
\text { adult family } \\
\text { members after } \\
\text { the death of a } \\
\text { parent }\end{array}$ & $\begin{array}{l}\text { Longitudinal, } \\
3 \text { evaluations: } \\
\text { T1- } 6 \text { weeks } \\
\text { T2 }-6 \text { months } \\
\text { T3 }-13 \\
\text { months after } \\
\text { the death }\end{array}$ & $\begin{array}{l}269 \text { family } \\
\text { members of } \\
\text { cancer patients } \\
\text { who had a } \\
\text { partner and at } \\
\text { least one child } \\
\text { older than } 12 \\
\text { years }\end{array}$ & $\begin{array}{l}\text {-FES (family } \\
\text { dynamics) } \\
\text {-FACES III (family } \\
\text { dyn.) } \\
\text { - BDI (depression) }{ }^{1} \\
\text {-BSI } \\
\text { (psychopathological } \\
\text { symptoms) } \\
\text { - BPQ (grief) }\end{array}$ & $\begin{array}{l}\text { Families were classified } \\
\text { into } 5 \text { typologies: } \\
\text { supportive families, } \\
\text { conflict resolving } \\
\text { families, intermediate } \\
\text { families, sullen families } \\
\text { and hostile families. } \\
\text { - family typologies at } \\
\text { T1 were predictors of } \\
\text { classifications at T2 } \\
\text { and T3, } \\
\text { - children were } \\
\text { classified as more } \\
\text { hostile than spouses. }\end{array}$ & 14 \\
\hline $\begin{array}{l}\text { Kissane, } \\
\text { Bloch, } \\
\text { Onghena, } \\
\text { McKenzie, } \\
\text { Snyder, \& } \\
\text { Dowe } \\
(1996 \mathrm{~b})^{10}\end{array}$ & Australia & $\begin{array}{l}\text { Describe } \\
\text { the intensity } \\
\text { of grief, } \\
\text { psychosocial } \\
\text { morbidity and } \\
\text { coping patterns } \\
\text { in family } \\
\text { members } \\
\text { according } \\
\text { to family } \\
\text { functioning } \\
\text { typology }\end{array}$ & $\begin{array}{l}\text { Longitudinal, } \\
3 \text { evaluations: } \\
\text { T1- } 6 \text { weeks } \\
\text { T2 }-6 \text { months } \\
\text { T3 }-13 \\
\text { months after } \\
\text { the death }\end{array}$ & $\begin{array}{l}269 \text { family } \\
\text { members of } \\
\text { cancer patients } \\
\text { who had a } \\
\text { partner and at } \\
\text { least one child } \\
\text { older than } 12 \\
\text { years }\end{array}$ & $\begin{array}{l}\text { - BPQ (grief) } \\
\text { - BDI (depression) } \\
\text {-BSI } \\
\text { (psychopathological } \\
\text { symptoms) } \\
\text {-SASn (social } \\
\text { functioning) } \\
\text {-FES (family } \\
\text { dynamics) } \\
\text {-FACES III (family } \\
\text { dynamics) } \\
\text { - Family Crisis } \\
\text { Oriented Personal } \\
\text { Evaluation Scales } \\
\text { (family coping) }\end{array}$ & $\begin{array}{l}\text { - more intense } \\
\text { grieving and greater } \\
\text { psychosocial morbidity } \\
\text { were found in } \\
\text { sullen, hostile and } \\
\text { intermediate families, } \\
\text { - sullen families had a } \\
\text { more intense grieving } \\
\text { process and greater } \\
\text { psychosocial morbidity } \\
\text { but made more use of } \\
\text { religion, social support } \\
\text { and community } \\
\text { resources, } \\
\text { - functional families } \\
\text { (supportive and } \\
\text { conflict resolving) had } \\
\text { better grief resolution, } \\
\text { made more adaptive } \\
\text { adjustments and used } \\
\text { more coping strategies, } \\
\text { - hostile and sullen } \\
\text { families had poorer } \\
\text { social adjustment, } \\
\text { were less functional at } \\
\text { work and had poorer } \\
\text { social and overall } \\
\text { functioning, } \\
\text {-hostile families had } \\
\text { less social support. }\end{array}$ & 16 \\
\hline
\end{tabular}




\begin{tabular}{|c|c|c|c|c|c|c|c|}
\hline \multicolumn{8}{|c|}{ Chart 1 . continuation } \\
\hline $\begin{array}{l}\text { Authors } \\
\text { and year }\end{array}$ & Country & Objective & Design & Population & Instruments & Results & $\begin{array}{l}\text { Quality } \\
\text { Eval. }\end{array}$ \\
\hline $\begin{array}{l}\text { Kissane, } \\
\text { McKenzie, } \\
\text { McKenzie, } \\
\text { Forbes, } \\
\text { O'Neill, \& } \\
\text { Bloch }(2003)^{11}\end{array}$ & Australia & $\begin{array}{l}\text { Assess } \\
\text { whether high } \\
\text { psychosocial } \\
\text { morbidity } \\
\text { levels are } \\
\text { associated } \\
\text { with } \\
\text { increasing } \\
\text { family } \\
\text { dysfunction }\end{array}$ & $\begin{array}{l}\text { Cross- } \\
\text { sectional }\end{array}$ & $\begin{array}{l}363 \text { family } \\
\text { members ( } 81 \\
\text { families) of } \\
\text { patients in } \\
\text { palliative care } \\
\text { at home; the } \\
\text { participants } \\
\text { had to have a } \\
\text { partner and } \\
\text { at least } 1 \text { child } \\
\text { aged } 12 \text { years } \\
\text { or older }\end{array}$ & $\begin{array}{l}\text { - FRI (family } \\
\text { dynamics) }^{\circ} \\
\text { - FAD (family } \\
\text { dynamics) } \\
\text { - BDI (depression) } \\
\text {-BSI } \\
\text { (psychopathological } \\
\text { symptoms) } \\
\text { - SAS (social } \\
\text { functioning) }\end{array}$ & $\begin{array}{l}\text { - greater psychosocial } \\
\text { morbidity in more } \\
\text { dysfunctional families, } \\
\text { - hostile families had } \\
\text { more depressed, anxious } \\
\text { and obsessive members } \\
\text { than other groups, higher } \\
\text { levels of distress and } \\
\text { poorer social adjustment, } \\
\text { - sullen families had } \\
\text { higher scores on the } \\
\text { psychosis and paranoid } \\
\text { ideation subscales, } \\
\text { - more dysfunctional } \\
\text { families had poorer } \\
\text { social, global, domestic } \\
\text { and leisure functioning. }\end{array}$ & 16 \\
\hline $\begin{array}{l}\text { Kissane, } \\
\text { McKenzie, } \\
\text { Bloch, } \\
\text { Moskowitz, } \\
\text { McKenzie, \& } \\
\text { O’Neill } \\
(2006)^{14}\end{array}$ & Australia & $\begin{array}{l}\text { Evaluate } \\
\text { the effects } \\
\text { of family- } \\
\text { oriented } \\
\text { grief therapy } \\
\text { in reducing } \\
\text { the morbid } \\
\text { effects of } \\
\text { grief among } \\
\text { families in } \\
\text { psychosocial } \\
\text { risk } \\
\text { situations }\end{array}$ & $\begin{array}{l}\text { Longitudinal, } \\
3 \text { evaluations: } \\
\text { T1 - start } \\
\text { of family- } \\
\text { focused grief } \\
\text { therapy } \\
\text { T2 - } 6 \text { months } \\
\text { after the } \\
\text { sick family } \\
\text { member's } \\
\text { death } \\
\text { T3 - } 13 \\
\text { months after } \\
\text { the sick family } \\
\text { member's } \\
\text { death }\end{array}$ & $\begin{array}{l}362 \text { family } \\
\text { members } \\
\text { ( } 81 \text { families) of } \\
\text { persons who } \\
\text { died of cancer } \\
2 \text { groups: } \\
\text { - Experimental } \\
\text { group } \\
\text { (therapy): } \\
53 \text { families } \\
\text { - Control } \\
\text { group: } 28 \\
\text { families }\end{array}$ & $\begin{array}{l}\text { - FRI (family } \\
\text { dynamics) } \\
\text { - FAD (family } \\
\text { dynamics) } \\
\text {-BSI } \\
\text { (psychopathological } \\
\text { symptoms) } \\
\text { - BDI (depression) } \\
\text { - SAS (social } \\
\text { functioning) } \\
\text { - BPQ (grief) }\end{array}$ & $\begin{array}{l}\text { - overall family } \\
\text { functioning did not } \\
\text { change, but sullen and } \\
\text { intermediate families } \\
\text { tended to improve, } \\
\text { - depression did not } \\
\text { change in hostile families, } \\
\text { - families with } \\
\text { intermediate functioning } \\
\text { in the experimental } \\
\text { group had a significantly } \\
\text { greater reduction in } \\
\text { conflict level than } \\
\text { intermediate families } \\
\text { in the control group } 6 \\
\text { months after the loss, } \\
\text { - hostile families in the } \\
\text { experimental group } \\
\text { deteriorated significantly } \\
\text { more than hostile } \\
\text { families in the control } \\
\text { group over the } 13 \\
\text { months of bereavement, } \\
\text { - the overall impact of } \\
\text { therapy was modest, with } \\
\text { a reduction in distress at } \\
\text { 13 months, } \\
\text { - individuals with high } \\
\text { distress and depression } \\
\text { scores at the initial } \\
\text { evaluation showed a } \\
\text { significant improvement } \\
\text { in these indices after } \\
\text { therapy. }\end{array}$ & 17 \\
\hline
\end{tabular}




\begin{tabular}{|c|c|c|c|c|c|c|c|}
\hline \multicolumn{8}{|c|}{ Chart 1 . continuation } \\
\hline $\begin{array}{l}\text { Authors } \\
\text { and year }\end{array}$ & Country & Objective & Design & Population & Instruments & Results & $\begin{array}{l}\text { Av. } \\
\text { Qual }\end{array}$ \\
\hline $\begin{array}{l}\text { Kramer, } \\
\text { Kavanaugh, } \\
\text { Trentham- } \\
\text { Dietz, } \\
\text { Walsh, \& } \\
\text { Yonker } \\
(2010)^{2}\end{array}$ & USA & $\begin{array}{l}\text { Analyze the } \\
\text { predictors of } \\
\text { complicated } \\
\text { grief symptoms } \\
\text { examining } \\
\text { the role of } \\
\text { family conflict, } \\
\text { intrapsychic } \\
\text { tensions, and } \\
\text { the moderating } \\
\text { effect of quality } \\
\text { of care in the } \\
\text { hospice }\end{array}$ & $\begin{array}{l}\text { Cross- } \\
\text { sectional }\end{array}$ & $\begin{array}{l}152 \text { family } \\
\text { members } \\
\text { (spouses and } \\
\text { children) of } \\
\text { persons who } \\
\text { died from } \\
\text { lung cancer }\end{array}$ & $\begin{array}{l}\text { - ICG (grief) } \\
\text { - FC-EOL } \\
\text { (family conflict) } \\
\text { - questions } \\
\text { developed by } \\
\text { the authors to } \\
\text { evaluate quality } \\
\text { of care and } \\
\text { patient needs }\end{array}$ & $\begin{array}{l}\text { - families with low levels of } \\
\text { conflict prior to the illness } \\
\text { and higher levels of conflict } \\
\text { at the patient's end of life } \\
\text { showed more complicated } \\
\text { grief symptoms, } \\
\text { - family members with } \\
\text { difficulty accepting the } \\
\text { disease and more fear of } \\
\text { the sick person's death were } \\
\text { more at risk of complicated } \\
\text { grief, } \\
\text { - low quality of care provided } \\
\text { to the patient and family was } \\
\text { associated with higher levels } \\
\text { of complicated grief. }\end{array}$ & 16 \\
\hline $\begin{array}{l}\text { Lohan \& } \\
\text { Murphy } \\
(2002)^{22}\end{array}$ & USA & $\begin{array}{l}\text { Compare the } \\
\text { perception } \\
\text { of family } \\
\text { functioning } \\
\text { in grieving } \\
\text { families } \\
\text { according to } \\
\text { the type of } \\
\text { violent death } \\
\text { and compare } \\
\text { parents } \\
\text { perception } \\
\text { of family } \\
\text { functioning } \\
\text { based on } \\
\text { parental } \\
\text { function }\end{array}$ & $\begin{array}{l}\text { Longitudinal, } \\
3 \\
\text { evaluations: } \\
-2-7 \text { months } \\
\text { after the } \\
\text { death, } \\
-12 \text { months } \\
\text { after the } \\
\text { death } \\
\text { - } 24 \text { months } \\
\text { after the } \\
\text { death }\end{array}$ & $\begin{array}{l}135 \text { parents } \\
\text { of teenagers } \\
\text { or young } \\
\text { adults } \\
\text { who died a } \\
\text { sudden or } \\
\text { violent death } \\
\text { who had at } \\
\text { least one } \\
\text { living child }\end{array}$ & $\begin{array}{l}\text {-FACES III } \\
\text { (family dyn.) }\end{array}$ & $\begin{array}{l}\text { - there were no differences in } \\
\text { family functioning based on } \\
\text { cause of death, } \\
\text { - only the adaptability scores } \\
\text { at the initial evaluation } \\
\text { were significantly greater } \\
\text { for parents whose children } \\
\text { committed suicide, } \\
\text { - mothers in the study } \\
\text { had higher scores on the } \\
\text { adaptability dimension than } \\
\text { fathers, } \\
\text { - grieving mothers and } \\
\text { fathers rated their families } \\
\text { as more flexible than the } \\
\text { general population, } \\
\text { - parents evaluated their } \\
\text { families as less close than the } \\
\text { general population. }\end{array}$ & 17 \\
\hline
\end{tabular}

In studies in which the participants were parents of children who had died of cancer, Drew et al. ${ }^{20}$ and Goodenough et al..$^{21}$ found no significant correlations between grief and family functioning. These authors noted, however, that the fathers and mothers of children who died in hospitals had higher depression results. Furthermore, fathers whose children died in the hospital reported significantly higher levels of depression, anxiety and stress, and the mothers of such children showed more complicated grief symptoms. In Drew et al.'s study ${ }^{20}$, parents whose children died while undergoing bone marrow transplantation showed relatively higher levels of depression, anxiety and stress, while parents of children who had a transplant and also died in the hospital were more likely to meet the criteria for complicated grief than parents whose deceased child had not had a transplant.

Nelson and Frantz ${ }^{26}$ investigated the family members of children and adolescents who died sudden or violent deaths (e.g., homicides, suicides and accidents). After comparing the effect of cause of death (suicide or non-suicide) on 


\begin{tabular}{|c|c|c|c|c|c|c|c|}
\hline \multicolumn{8}{|c|}{ Chart 1. continuation } \\
\hline $\begin{array}{l}\text { Authors } \\
\text { and year }\end{array}$ & Country & Objective & Design & Population & Instruments & Results & $\begin{array}{c}\text { Quality } \\
\text { Eval. }\end{array}$ \\
\hline $\begin{array}{l}\text { Lohan \& } \\
\text { Murphy } \\
(2006)^{23}\end{array}$ & USA & $\begin{array}{l}\text { Evaluate } \\
\text { mental distress } \\
\text { and family } \\
\text { functioning of } \\
\text { parents who } \\
\text { lost a child } \\
\text { to sudden } \\
\text { death and } \\
\text { compare with } \\
\text { the general } \\
\text { population }\end{array}$ & $\begin{array}{l}\text { Longitudinal, } \\
3 \text { evaluations: } \\
\text { T1 - 4-7 } \\
\text { months after } \\
\text { death } \\
\text { T2 - } 6 \text { months } \\
\text { after T1 } \\
\text { T3 - } 18 \\
\text { months after } \\
\text { T1 }\end{array}$ & $\begin{array}{l}32 \text { couples } \\
\text { whose teenage } \\
\text { or young } \\
\text { adult children } \\
\text { died suddenly } \\
\text { by accident, } \\
\text { suicide or } \\
\text { homicide }\end{array}$ & $\begin{array}{l}\text { - FACES III } \\
\text { (family dyn.) } \\
\text { - BSI } \\
\text { (psychopathological } \\
\text { symptoms) }\end{array}$ & $\begin{array}{l}\text { - at T2 (1 year after the } \\
\text { loss), parents who lost } \\
\text { a child to sudden death } \\
\text { had a lower level of } \\
\text { cohesion than parents in } \\
\text { the general population, } \\
\text { - mothers had } \\
\text { significantly higher } \\
\text { scores than fathers in } \\
\text { the general symptom } \\
\text { index at T2 and T3, } \\
\text { - fathers at T2 showed } \\
\text { a significant negative } \\
\text { correlation between } \\
\text { general symptom index } \\
\text { and cohesion scores. }\end{array}$ & 16 \\
\hline $\begin{array}{l}\text { Lohan \& } \\
\text { Murphy } \\
(2006)^{24}\end{array}$ & USA & $\begin{array}{l}\text { Deepen } \\
\text { understanding } \\
\text { of the } \\
\text { relationship } \\
\text { between } \\
\text { mental distress } \\
\text { and family } \\
\text { functioning } \\
\text { among parents } \\
\text { who have lost a } \\
\text { child through } \\
\text { violent death }\end{array}$ & $\begin{array}{l}\text { Longitudinal, } \\
3 \text { evaluations: } \\
\text { T1 }-4 \text { months } \\
\text { T2 }-12 \\
\text { months } \\
\text { T3 - } 24 \\
\text { months after } \\
\text { the death }\end{array}$ & $\begin{array}{l}30 \text { sets of } \\
\text { parents who } \\
\text { lost a child } \\
\text { through } \\
\text { traumatic/ } \\
\text { violent death }\end{array}$ & $\begin{array}{l}\text { - FACES III } \\
\text { (family dyn.) } \\
\text { - BSI } \\
\text { (psychopathological } \\
\text { symptoms) }\end{array}$ & $\begin{array}{l}\text { - mothers participating } \\
\text { in the study were more } \\
\text { often classified as } \\
\text { adaptable than chaotic } \\
\text { both } 4 \text { and } 12 \text { months } \\
\text { after the loss of the } \\
\text { child; they were also } \\
\text { more often classified } \\
\text { as connected and } \\
\text { entangled at } 4 \text { and } 12 \\
\text { months, and after the } \\
\text { loss, most mothers were } \\
\text { classified as entangled, } \\
\text { - fathers were typically } \\
\text { classified as adaptable } \\
4 \text { months after the } \\
\text { loss rather than rigid } \\
\text { or structured, but at } \\
12 \text { months, they were } \\
\text { more often classified } \\
\text { as flexible; they were } \\
\text { also classified more as } \\
\text { connected } 4 \text { and } 12 \\
\text { months after the loss. }\end{array}$ & 16 \\
\hline
\end{tabular}

family dynamics, the authors found no significant differences in the perceived closeness of family members before or after the death. However, surviving siblings mentioned feeling closer to their parents after their sibling's death than before. In families with higher levels of family conflict, parents reported feeling more distant from their surviving children, and families classified as disconnected or conflicted also reported greater distance. Cohesive or expressive families, however, reported more closeness among family members. In a study by Lohan and Murphy ${ }^{22}$, no differences were found in family functioning based on cause of death, though adaptability scores at initial evaluation were significantly higher for parents whose children had committed suicide. 
Chart 1. continuation

\begin{tabular}{|c|c|c|c|c|c|c|c|}
\hline $\begin{array}{l}\text { Authors } \\
\text { and year }\end{array}$ & Country & Objective & Design & Population & Instruments & Results & $\begin{array}{l}\text { Quality } \\
\text { Eval. }\end{array}$ \\
\hline $\begin{array}{l}\text { Lohan \& } \\
\text { Murphy } \\
(2007)^{25}\end{array}$ & USA & $\begin{array}{l}\text { Determine } \\
\text { whether there } \\
\text { were significant } \\
\text { differences } \\
\text { in family } \\
\text { functioning } \\
\text { between } \\
\text { married and } \\
\text { unmarried } \\
\text { grieving } \\
\text { mothers } \\
\text { and whether } \\
\text { marital status } \\
\text { affected family } \\
\text { functioning } \\
\text { over time }\end{array}$ & $\begin{array}{l}\text { Longitudinal, } \\
3 \text { evaluations: } \\
-2 \text { to } 7 \\
\text { months after } \\
\text { the death, } \\
\text { - } 6 \text { months } \\
\text { after the } 1 \text { st } \\
\text { evaluation } \\
-18 \text { months } \\
\text { after the } 1 \text { st } \\
\text { evaluation }\end{array}$ & $\begin{array}{l}86 \text { mothers } \\
\text { who lost } \\
\text { a child } \\
\text { (between } 12 \\
\text { and } 28 \text { years } \\
\text { old) to violent } \\
\text { death, who } \\
\text { had at least } \\
\text { one living } \\
\text { child }\end{array}$ & $\begin{array}{l}\text { - FACES III } \\
\text { (family dyn.) }\end{array}$ & $\begin{array}{l}\text { - there were no significant } \\
\text { differences between the } \\
\text { married mothers and the } \\
\text { single mothers regarding } \\
\text { family functioning, } \\
\text { - civil status was not } \\
\text { a predictor of family } \\
\text { functioning, and marriage } \\
\text { was not a protective } \\
\text { factor as families adapted } \\
\text { to the death of a child, } \\
\text {-single mothers with } \\
\text { limited financial resources } \\
\text { are not necessarily poor in } \\
\text { the resources required to } \\
\text { maintain family cohesion } \\
\text { and adaptability over } \\
\text { time. }\end{array}$ & 18 \\
\hline $\begin{array}{l}\text { Nelson \& } \\
\text { Frantz } \\
(1996)^{26}\end{array}$ & USA & $\begin{array}{l}\text { Study the } \\
\text { effects of a } \\
\text { child's death } \\
\text { by suicide } \\
\text { and compare } \\
\text { it with the } \\
\text { effects of non- } \\
\text { suicide deaths } \\
\text { on family } \\
\text { dynamics }\end{array}$ & $\begin{array}{l}\text { Cross- } \\
\text { sectional }\end{array}$ & $\begin{array}{l}41 \text { parents } \\
\text { and } 39 \\
\text { siblings }\end{array}$ & $\begin{array}{l}\text { - Bloom's Family } \\
\text { Scales (family } \\
\text { functioning) } \\
\text { - Closeness } \\
\text { / Distance } \\
\text { Questionnaire } \\
\text { (closeness of } \\
\text { relationship; } \\
\text { developed by the } \\
\text { authors) }\end{array}$ & $\begin{array}{l}\text { - disconnected or } \\
\text { conflicted families } \\
\text { experienced greater } \\
\text { distance, while cohesive } \\
\text { or expressive families } \\
\text { reported more closeness, } \\
\text { - the more conflicted the } \\
\text { family members, the more } \\
\text { distant parents reported } \\
\text { feeling from the surviving } \\
\text { children, } \\
\text { - surviving siblings felt } \\
\text { closer to their parents } \\
\text { after the death than } \\
\text { before, } \\
\text { - there were no differences } \\
\text { among family members } \\
\text { of suicide victims and } \\
\text { those of people whose } \\
\text { death was not the result } \\
\text { of suicide in perceived } \\
\text { closeness among family } \\
\text { pairs before or after death. }\end{array}$ & 16 \\
\hline
\end{tabular}

The mothers studied had higher scores in the adaptability dimension than the fathers. Fathers rated their families as less close than the general population, but both grieving fathers and mothers rated their families as more flexible than the general population.

Another 2006 study by the same authors ${ }^{23}$ evaluated the mental distress and family func- tioning of parents who lost a child to sudden death and compared these results to the general population. The authors found that one year after the death, parents who had lost a child to sudden death had lower levels of cohesion than parents in the general population. Mothers had significantly higher scores than fathers on the general symptom index (BSI) one and two years 
Chart 1. continuation

\begin{tabular}{|c|c|c|c|c|c|c|c|}
\hline $\begin{array}{l}\text { Authors } \\
\text { and year }\end{array}$ & Country & Objective & Design & Population & Instruments & Results & $\begin{array}{c}\text { Quality } \\
\text { Eval. }\end{array}$ \\
\hline $\begin{array}{l}\text { Traylor, } \\
\text { Hayslip, } \\
\text { Kaminski, } \\
\text { \& York, } \\
(2013)^{12}\end{array}$ & USA & $\begin{array}{l}\text { Assess whether } \\
\text { the grieving } \\
\text { process } \\
\text { affects the } \\
\text { characteristics } \\
\text { of relationships } \\
\text { within the } \\
\text { family system } \\
\text { or whether } \\
\text { family } \\
\text { characteristics } \\
\text { affect the } \\
\text { grieving } \\
\text { process }\end{array}$ & $\begin{array}{l}\text { Longitudinal, } \\
2 \text { evaluations: } \\
\text { T1 - 4-5 } \\
\text { weeks after } \\
\text { the death } \\
\text { T2 - } 6 \text { months } \\
\text { after the 1st } \\
\text { evaluation }\end{array}$ & $\begin{array}{l}61 \text { family } \\
\text { members who } \\
\text { lost a parent } \\
\text { or spouse }\end{array}$ & $\begin{array}{l}\text { - FES (family } \\
\text { dyn.) } \\
\text { - FAM (family } \\
\text { dyn.) } \\
\text { GEI }\left(\text { grief) }{ }^{\mathrm{r}}\right.\end{array}$ & $\begin{array}{l}\text { - greater cohesion at } \mathrm{T} 1 \\
\text { was a predictor of fewer } \\
\text { grief symptoms at } \mathrm{T} 2 \text {, } \\
\text { - families that more freely } \\
\text { expressed affection, had } \\
\text { better cohesion and had } \\
\text { better communication } \\
\text { among family members } \\
\text { at } \mathrm{T} 1 \text { showed less intense } \\
\text { grief at } \mathrm{T} 2 \text {, } \\
\text { - there was no difference } \\
\text { between people who lost a } \\
\text { parent and those who lost } \\
\text { a spouse. }\end{array}$ & 18 \\
\hline
\end{tabular}

${ }^{\mathrm{a}}$ FACES III - Family Adaptability and Cohesion Evaluation Scale, ${ }^{\mathrm{b}}$ TRIG - Texas Revised Inventory of Grief, ${ }^{\mathrm{c} B S I}$ - Brief Symptom Inventory, ${ }^{\mathrm{d}}$ DASS21 - Depression Anxiety Stress Scale, ${ }^{\mathrm{e}}$ CBI - Core Bereavement Inventory, ${ }_{\mathrm{f}}^{\mathrm{f}} \mathrm{CG}$ - Inventory of Complicated Grief, ${ }_{\mathrm{g}}^{\mathrm{g}} \mathrm{FAD}$ - Family Assessment Device, ${ }^{\mathrm{h}}$ FILE - Family Inventory of Life Events, ${ }^{i}$ FHQ - Family History Questionnaire, ${ }^{j}$ FIF - Family Information Form, ${ }^{k}$ FES - Family Environment Scale, ${ }^{1}$ BDI - Beck Depression Inventory, ${ }^{\mathrm{m}} \mathrm{BPQ}$ - Bereavement Phenomenology Questionnaire, ${ }^{\mathrm{n}} \mathrm{SAS}$ - Social Adjustment Scale, ${ }^{\circ} \mathrm{FRI}$ - Family Relationship Index, ${ }^{\mathrm{p}}$ FC-EOL - Family Conflict at the End of Life, ${ }^{\mathrm{q}} \mathrm{FAM}$ - Family Assessment Measure, ${ }^{\mathrm{r}} \mathrm{GEI}$ - Grief Experience Inventory.

Table 1. Instruments used to evaluate family dynamics.

\begin{tabular}{cc}
\hline Instrument & $\begin{array}{c}\text { Number of studies using } \\
\text { the instrument }\end{array}$ \\
\hline FACES & 8 \\
FAD & 4 \\
FES & 3 \\
FRI & 2 \\
FC-EOL & 1 \\
FAM & 1 \\
Bloom's Family Scales & 1 \\
\hline
\end{tabular}

Table 2. Instruments used to evaluate grief.

\begin{tabular}{cc}
\hline Instrument & $\begin{array}{c}\text { Number of studies using } \\
\text { the instrument }\end{array}$ \\
\hline BPQ & 3 \\
ICG & 3 \\
TRIG & 1 \\
CBI & 1 \\
GEI & 1 \\
\hline
\end{tabular}

after the loss. In addition, one year after the loss, a significant negative correlation between general symptom index scores and cohesion was found among fathers ${ }^{23}$. The results of a third study by the same authors published in $2006^{24}$ showed that the mothers participating in the study were more often classified as adaptable than chaotic both four and 12 months after the loss of a child. This result represents an extremely high level of adaptability. With respect to cohesion, the mothers were more often classified as connected and entangled at four months; i.e., they showed a moderately high to extremely high level of cohesion. At 12 months after the loss, most mothers were classified as entangled (extremely high cohesion). Fathers' adaptability four months after the loss, however, was more often classified as rigid or structured, indicating a low or extremely low level of adaptability. At 12 months, however, they were classified as flexible, with moderately high adaptability. With regard to cohesion, fathers were typically classified as connected at four months and 12 months after the loss ${ }^{24}$; i.e., they presented a moderately high level of cohesion.

Only mothers participated in Lohan and Murphy's 2007 study ${ }^{25}$, which sought to determine whether there were significant differences in family functioning among grieving married and single mothers. The authors found no significant differences between groups of married mothers and single mothers, indicating that marital status is not a predictor of family function- 
ing and that marriage should not be considered a protective factor that helps families adapt to a child's death. The study also revealed that single mothers with limited financial resources are not necessarily poor in the resources required to maintain family cohesion and adaptability over time and that a low income is not associated with the inability to access resources.

The quality evaluation showed that the selected articles had, on a scale that ranged from 0 to 20 , scores between 14 and 18 , which indicates that the studies were of good quality.

\section{Discussion}

According to this review, few articles have been published about family dynamics during the grieving process, indicating that the subject is under-studied. Investigations of this topic are concentrated in just two countries (the USA and Australia).

The earliest relevant articles appear in the early 1990s, beginning with a study by Jordan ${ }^{21}$ in which the target population was not specified. The data presented described the difficulties and grievances of families after the loss of a loved one. The subsequent work of the Australian group led by David Kissane is noteworthy. This group was responsible for four of the selected articles and for more than half of the studies on families with cancer patients. This group's first two articles were published in 1996 in the same journal. This study appears to be an initial attempt to systematize the evaluation of grieving families of cancer patients to facilitate their classification into family functioning types. Such classification allows less functional families to received needed support and monitoring. In their research, this Australian group created a family-oriented grief intervention model ${ }^{14,27}$ to provide appropriate treatment and support for grieving families. Their study showed that some family typologies are likely to benefit from this intervention model ${ }^{14}$.

The selected studies provided evidence that poor family functioning is associated with increased psychopathological symptoms (anxiety, depression and psychological distress), a more complicated grieving process, greater psychosocial morbidity and poor social functioning, little or no social support, difficulty accessing community resources or seeking spiritual support and lower functional capacity at work w., $^{2,9-12,14}$. Family conflicts were also identified as a factor that may contribute to the development of com- plicated grief ${ }^{17}$. The most recent article selected was conducted by Traylor et al. ${ }^{12}$. It emphasized that cohesion, expression of affection and good communication in families can significantly mitigate grief symptoms.

The two articles (published in 2004 and $2005^{19,20}$ ) that examined the influence of family dynamics on the grieving process of parents whose children died of cancer found no significant effect of family functioning. Lohan and Murphy are responsible for almost all the research involving the relatives of children and adolescents who died a sudden or violent death (homicide, suicide and accidents), and most of their publications were published between 2002 and 2007. The results of these authors' studies do not offer a consensus about the effect of family functioning on parents and their levels of cohesion and adaptability at each of the evaluation time points. This divergence seems to indicate that such discrepancies in the perception of family dynamics may be attributable to the characteristics of the individual, the couple and the family itself, characteristics that may change over time.

With regard to methodology, the studies investigated diverse sample sizes and populations. The instruments used to evaluate the variables were also varied. Although all the family functioning evaluation tools measure cohesion among family members, each instrument classifies families according to a different typology, making it difficult to compare the studies and generalize results.

\section{Final considerations}

This study conducted a systematic review of the literature on the effect of family dynamics on adult family members' grieving process. Few relevant studies were found, indicating that family functioning during the care phase and especially during the grieving process has received little attention from researchers. Most of the studies reviewed only evaluated families during the grieving period, and some only evaluated families during the family member's disease stage but did not conduct a longitudinal evaluation of family dynamics that encompassed both the care stage and the grief period. Such an approach could provide more information about family functioning.

This review compiles the studies published on the subject, surveys the instruments used to evaluate family dynamics and grief and summa- 
rizes the results of the articles. The studies confirmed that dysfunctional families experience more complications during the grieving period, which can lead to a more intense and prolonged grieving process. The more intense psychopathological symptoms and greater psychosocial morbidity experienced by these families may also be associated with complicated grief.

Therefore, it would be interesting to use a screening tool to evaluate family dynamics, preferably during the care period or at the beginning of the grieving process. Such a tool would allow professionals to identify families with poor family functioning who may have an increased risk of developing complications during bereavement and therefore need additional support.

It would also be of academic interest to increase the study sample sizes and standardize the instruments and the data collection methodology to enable subsequent comparison and generalization of the results.

One of the limitations of the present study is that the articles in the sample were limited to texts in English, Portuguese or Spanish that had already been published in scientific journals, which excludes Master's theses, doctoral dissertations and conference papers. Furthermore, the electronic database search was limited to EBSCO, Web of Knowledge and Bireme.

A bias may have been introduced into the review process by the fact that the initial screening of the abstracts and the application of the inclusion/exclusion criteria to select the 40 potentially eligible studies were performed only by the first author. Furthermore, it was not possible to access the full text of one of the selected articles.
In addition, the instrument used to evaluate the quality of the studies and the scoring system were created by the authors of the present article based on an evaluation criteria checklist used in observational studies.

\section{Collaborators}

M Delalibera was responsible for the search, selection and evaluation of the articles, data interpretation and the production of the manuscript. J Presa was responsible for the search and selection of the articles. A Coelho was responsible for resolving doubts and differences during the article selection process and collaborated in the drafting of the manuscript. A Barbosa was responsible for the critical review of the manuscript, and MH Franco was responsible for the critical review and collaborated in writing the final manuscript.

\section{Acknowledgments}

We express thanks to the Coordination for the Improvement of Higher Education Personnel (Coordenação de Aperfeiçoamento de Pessoa de Nível Superior - CAPES). This study comprises part of the first author's doctoral research, which was conducted abroad as a CAPES scholar. 


\section{References}

1. Queiroz AHAB, Pontes RJS, Souza AMA, Rodrigues TB. Percepção de familiares e profissionais de saúde sobre os cuidados no final da vida no âmbito da atenção primária à saúde. Cien Saude Colet 2013;18(9):26152623.

2. Kramer BJ, Kavanaugh M, Trentham-Dietz A, Walsh M, Yonker JA. Complicated grief symptoms in caregivers of persons with lung cancer: The role of family conflict, intrapsychic strains, and hospice utilization. Omega J Death Dying 2010; 62(3):201-220.

3. Nadeau JW. Meaning making in family bereavement: A family systems approach. In: StroebeMS, Hansson RO, Stroebe W, Schut H, editors. Handbook of bereavement research: Consequences, coping and care. Washington: American Psychological Association; 2001. p. 329-347.

4. Stroebe W, Schut H. Models of coping with bereavement: A review. In: Stroebe MS, Hansson RO, Stroebe $\mathrm{W}$, Schut $\mathrm{H}$, editors. Handbook of bereavement research: Consequences, coping and care. Washington: American Psychological Association; 2001. p. 376-404.

5. Shapiro ER. Grief in interpersonal perspective: Theories and their implications. In: Stroebe MS, Hansson RO, Stroebe W,Schut H, editors. Handbook of bereavement research: Consequences, coping and care.Washington, DC: American Psychological Association; 2001. p. 301-328.

6. Schuler T, Zaider T, Kissane D. Family grief therapy:A vital model in oncology, palliative care andbereavement. Fam Matters 2012; (90):77-86.

7. Brintzenhofszoc KM, Smith ED, Zabora JR. Screening to Predict Complicated Grief in Spouses of. Cancer Pract 1999; 7(5):233-239.

8. Hudson PL, Hayman-White K, Aranda S, Kristjanson LJ. Predicting family caregiver psychosocial functioning in palliative care. J Palliat Care 2006; 22(3):133140.

9. Kissane DW, Bloch S, Dowe DL, Snyder RD, Onghena P, McKenzie DP, Wallace CS. The Melbourne Family Grief Study, I: Perceptions of family functioning in bereavement. Am J Psychiat 1996; 153(5):650-658.

10. Kissane DW, Bloch S, Onghena P, McKenzie DP, Snyder RD, Dowe DL. The Melbourne Family Grief Study, II: Psychosocial morbidity and grief in bereaved families. Am J Psychiat 1996; 153(5):659-666.

11. Kissane DW, McKenzie M, McKenzie DP, Forbes A, O’Neill I, Bloch S. Psychosocial morbidity associated with patterns of family functioning in palliative care: baseline data from the Family Focused Grief Therapy controlled trial. Palliat Med 2003; 17(6):527-537.

12. Traylor ES, Hayslip B, Kaminski PL, York C. Relationships between grief and family system characteristics: a cross lagged longitudinal analysis. Death Stud 2013; 27(7):575-601.

13. Moos RH, Moos BS. Family Environment Scale Manual. California: Consulting Psychologists Press; 1981.

14. Kissane DW, McKenzie M, Bloch S, Moskowitz C, McKenzie DP, O'Neill I. Family focused grief therapy: a randomized, controlled trial in palliative care and bereavement. Am J Psychiat 2006; 163(7):1208-1218.

15. Kramer BJ, Boelk A, Auer C. Family conflict at the end -of-life: Lessons learned in a model program for vulnerable older adults. J Palliat Med 2006; 9:791-801.
16. Kissane DW, Bloch S, Miach P, Smith GC, Seddon A, Keks N. Cognitive-existential group therapy for patients with primary breast cancer-techniques and themes. Psychooncology 1997; 6(1):25-33.

17. Kramer BJ, Kavanaugh M, Trentham-Dietz A, Walsh M, Yonker JA. Predictors of Family Conflict at the End of Life: The Experience of Spouses and Adult Children of Persons with Lung Cancer. Gerontologist 2010; 50(2):215-225.

18. Von Elm E, Altman DG, Egger M, Pocock SJ, Gøtzsche PC, Vandenbroucke JP. The Strengthening the Reporting of Observational Studies in Epidemiology (STRO$\mathrm{BE})$ statement: guidelines for reporting observational studies. PLoS med 2007; 4(10):1623-1627.

19. Jordan JR. Cumulative Loss, Current Stress, and the Family: A Pilot Investigation of Individual and Systemic Effects. Omega J Death Dying 1992; 24(4):309-332.

20. Drew D, Goodenough B, Maurice L, Foreman T, Willis L. Parental grieving after a child dies drom cancer: is stress from stem cell transplant a factor?Int J Palliat Nurs 2005; 11(6):266-273.

21. Goodenough B, Drew D, Higgins S, Trethewie S. Bereavement outcomes for parents who lose a child to cancer: are place of death and sex of parent associated with differences in psychological functioning? Psychooncology 2004; 13(11):779-791.

22. Lohan J, Murphy S. Family functioning and family typology after an adolescent or young adult's sudden violent death. J Fam Nurs 2002; 8(1):32-49.

23. Lohan J, Murphy S. Mental Distress and Family Functioning Among Married Parents Bereaved By a Child'S Sudden Death. Omega J Death Dying 2006; 52(4):295305.

24. Lohan J, Murphy S. Mental Distress and Family Functioning in Bereaved Parents: Case Examples and Intervention Challenges. Omega J Death Dying 2006; 52(4):307-321.

25. Lohan J, Murphy S. Bereaved Mothers' Marital Status and Family Functioning After a Child's Sudden, Violent Death: A Preliminary Study. J Fam Nurs 2007; 12(4):333-347.

26. Nelson BJ, Frantz TT. Family Interactions of Suicide Survivors and Survivors of Non-Suicidal Death. Omega J Death Dying 1996; 33(2):131-146.

27. Kissane DW, Bloch S, McKenzie M, McDowall AC, Nitzan R. Family grief therapy: a preliminary account of a new model to promote healthy family functioning during palliative care and bereavement. Psychooncology 1998; 7(1):14-25.

Article submitted 06/03/2014

Approved 08/05/2014

Final version submitted 10/08/2014 